J. Product. \& Dev., 24(4): $869-883(2019)$

\title{
EVALUATES THE POSSIBLE RISK OF POLLEN GRAINS CONTAMINATION BY PESTICIDE RESIDUES AND THEIR AFFECTS ON HONEY BEE SURVIVAL
}

\author{
E. A. El-Hady ; H.M. El-Sharkawy**; R.E. Sanad ${ }^{*}$ \\ * Plant Protection Research Institute, Agricultural Research Center, Zagazig, Egypt. \\ ** Plant Production Department, Faculty of Technology and Development, Zagazig Univ., Egypt. \\ hamzash@hotmail.com,walaareda52@yahoo.com
}

\begin{abstract}
Some studies have suggested that extensive use of insecticides might be a factor in the increased rates of honey bee colonies loss during the dormant period. There for we conducted this study in five villages in Sharkia governorate, Egypt during 2017.

The obtained results revealed that the remarkable differences in residue levels between sites depending on the agricultural intensity were found. We found different pesticides in all observation sites. We found many samples under any detectable contamination and the few positive samples only with low concentrations of pesticides. Thiamethoxam at El-Nakhas and Ezbet Issa and imidacloprid at Plant protection Institute, Belbeis and El-Mahmodia record a higher PHQ more than 1000 corresponds to consuming more than $1 \%$ of the median lethal dose (LD50) per day and therefore represent the toxicity of substances to honey.

Conclusively, from these results it could be concluded that risks by ingestion of contaminated pollen and honey are of some concern for systemic insecticides, particularly imidacloprid and thiamethoxam, chlorpyrifos and the mixtures of cyhalothrin and ergosterol inhibiting fungicides. However, residues of neonicotinoid insecticides pose the highest risk by contact exposure of bees with contaminated pollen.

Keywords: Insecticides, HPLC, Honey bee, Apis mellifera, Health risk, Pollen, Egypt.
\end{abstract}

\section{INTRODUCTION}

Bees and other pollinators responsible for pollination of crops have been an integral part of agriculture for many centuries. Approximately $35 \%$ of crops depend directly on pollinators as shown by Klein et al., 1987.

While there are many factors that can potentially affect survival of bees, including changes in climate, genetics, changes in nutrition due to 
changes in cropping patterns from year to year, parasites and viral diseases (Fairbrother et al., 2014), results of some studies have suggested that extensive use of insecticides might be a factor in the increased rates of loss of colonies during the dormant period of winter (Cutler et al., 2014).

Neonicotinoid insecticides are also used on turf, as systemic insecticides injected into trees, in structures and outdoor residential areas, and in pet care products. Seeds of several major crops grown on the Canadian prairies, including canola, wheat, barley, oats and field peas are commonly coated with one of the neonicotinoid active ingredients clothianidin, imidacloprid, or thiamethoxam while acetamiprid is also used on fruit or leafy vegetable crops (Main et al., 2014).

Since 2002, in the UK and Japan, there has been a significant increase in use of thiamethoxam compared to other NIs, (Simon-Delso et al., 2015). Consequently, the worldwide sales of thiamethoxam reached US \$1 billion in 2011 (Syngenta, 2012), and US \$1.1 billion in 2012 (Syngenta, 2013).

An individual study on pollen residues evaluates the possible risk of such residues to honey bees by both contact with and ingestion of contaminated pollen (Stoner and Eitzer, 2013). Neither study, however, includes the frequency of contaminated pollen among the risk parameters, while they also ignore the residues in honey or nectar. This we consider a serious flaw, as risk assessments should be based on the probability of exposure to actual residue levels. Indeed, none of the frequency data from the surveys mentioned above have been used to assess the impact that individual chemical residues and their combinations may or may not have on bees.

Neonicotinoids are one of the most widely used classes of pesticides. In 2010 approximately 20,000 tonnes of active ingredient were used globally which constituted approximately one third of all insecticide treatments (Bonmatin et al., 2015). Neonicotinoids are persistent in the environment, water soluble but exhibit relatively lesser acute potencies toward fish, exhibit greater toxic potencies to invertebrates, particularly arthropods compared to vertebrates, systemic and are accumulated into the tissues of plants, including pollen (Bonmatin et al., 2015).

Codling et al. (2016) mentioned that neonicotinoid insecticides (NIs) and their transformation products were detected in honey, pollen and honey bees, (Apis mellifera) from hives located within $30 \mathrm{~km}$ of the City of Saskatoon, Saskatchewan, Canada. Clothianidin and thiamethoxam were the most frequently detected NIs, found in 68 and $75 \%$ of honey samples at mean concentrations of 8.2 and $17.2 \mathrm{ng}$ g_1 wet mass, (wm), respectively. 
Clothianidin was also found in $>50 \%$ of samples of bees and pollen.

Botías et al. (2015) collected pollen and nectar from wildflowers growing in field margins adjacent to agricultural fields planted with neonicotinoid-treated oilseed rape and wheat. Pollen samples from 54 wild flower species were collected. Thiamethoxam, imidacloprid and thiacloprid were all detected.

Thiamethoxam was the most frequently encountered neonicotinoid, and levels were highly variable with the highest concentrations found in Heracleum sphondylium at $86 \mathrm{ng} / \mathrm{g}$ and Papaverrhoeas at $64 \mathrm{ng} / \mathrm{g}$. There was substantial variation in the levels of contamination in the same wildflower species found in different field margins. Average levels of total neonicotinoid contamination in wildflower pollen were significantly higher in margins adjacent to treated oilseed rape (c. $15 \mathrm{ng} / \mathrm{g}$ ) than for margins adjacent to treated wheat (c. $0.3 \mathrm{ng} / \mathrm{g}$ ). Levels of neonicotinoids were much lower in wild plant nectar. Only thiamethoxam was detected at average levels of $0.1 \mathrm{ng} / \mathrm{g}$ in wild flowers adjacent to oilseed rape fields and $<0.1$ ng/g adjacent to wheat fields. Botías et al. (2015) is the only available study which has specifically measured neonicotinoid concentrations in pollen and nectar directly taken from wild plants growing in close proximity to neonicotinoid-treated crops.

Mogren and Lundgren (2016) assessed neonicotinoid concentrations in the nectar of five wild flower species sown as part of pollinator conservation measures which were located adjacent to neonicotinoid-treated maize. This was achieved by collecting honeybees seen to visit these flowers for nectar and extracting the contents of their crop for neonicotinoid residue analysis. Honeybees generally have a very high fidelity to visiting the same flower species on a single forage flight so the authors assumed that the nectar was representative of that particular species. Average clothianidin concentrations found in this nectar ranged between 0.2 and $1.5 \mathrm{ng} / \mathrm{g}$, with significant differences found between wild plant species. Mogren and Lundgren (2016) also tested the foliage of seven wildflower species for neonicotinoid residues directly. There was high variability in clothianidin uptake between and within plant species. Sunflowers Helianthus annuus accumulated the highest levels with concentrations of $0-81 \mathrm{ng} / \mathrm{g}$, with buckwheat Fagopyrume sculentum and phacelia Phacelia tanacetifolia accumulating lower levels at $0-52$ and $0-33 \mathrm{ng} / \mathrm{g}$ respectively. Similarly, high levels of variation were found by Botías et al. (2016) who sampled the foliage of 45 species of wild plant in field margins adjacent to treated oilseed rape crops. Average total neonicotinoid contamination was $10 \mathrm{ng} / \mathrm{g}$, with the highest levels seen in creeping thistle Cirsiumarvense of $106 \mathrm{ng} / \mathrm{g}$ 
of thiamethoxam.

Pecenka and Lundgren (2015) looked specifically at clothianidin concentrations in milkweed Asclepias syriaca in field margins adjacent to clothianidin-treated maize. Levels were lower than the previous two studies, with mean levels of $0.58 \mathrm{ng} / \mathrm{g}$ with a maximum concentration of $4.02 \mathrm{ng} / \mathrm{g}$. Whilst not looking at specific concentrations in pollen, nectar or foliage, Stewart et al. (2014); Rundlöf et al. (2015) found total mean neonicotinoid concentrations of 10 and $1 \mathrm{ng} / \mathrm{g}$ respectively in whole wild flower samples collected around neonicotinoid-treated fields.

\section{MATERIALS AND METHODS}

\section{Sample collection and handling:}

Pollens were collected from 5 villages in Sharkia governorate, Egypt during 2017. Pollen was collected by cutting $6 \mathrm{~cm}^{2}$ piece of comb containing stored pollen using a disposable plastic knife and placed in $15 \mathrm{~mL}$ Falcon tube.

\section{Extraction and cleanup}

Samples were brought to room temperature and extracted by use of a modified QuEChRS method (Codling et al. 2016). Pollens, ( $2 \mathrm{~g})$ having been extracted from the comb were weighed and homogenized by use of a precleaned, glass pestle and mortar with 1-2 g of baked NaSO4, followed by transfer to 50-mL Falcon tubes, then $10 \mathrm{~mL}$ of nanopure water introduced. Sample was vortexed for $1 \mathrm{~min}$ and shaken for $20 \mathrm{~min}$, after which $10 \mathrm{~mL}$ of acetonitrile (ACN), was added and the sample vortexed and shaken again. In 15-mL Falcon tubes $4 \mathrm{~g} \mathrm{MgSO} 4,1 \mathrm{~g} \mathrm{NaCL}, 1 \mathrm{~g}$ trisodium citrate and $0.5 \mathrm{~g}$ disodium hydrogen citrate was prepared. A second Falcon tube containing 900 mg MgSO4 $150 \mathrm{mg}$ primary secondary amine (PSA) for use later was also prepared. Samples were shaken for $15 \mathrm{~min}$ and centrifuged at $3000 \mathrm{~g}$ for $5 \mathrm{~min}$. Eight $\mathrm{mL}$ of the upper solvent $(\mathrm{ACN})$ was pipetted to the second prepared 15$\mathrm{mL}$ falcon tube. This was then vortexed and shaken for $15 \mathrm{~min}$ before centrifuging at $3000 \mathrm{~g}$ for $5 \mathrm{~min}, 6 \mathrm{~mL}$ of the supernatant was passed through a syringe filter ( $13 \mathrm{~mm} \varnothing, 2 \mathrm{~mm}$ nylon syringe filter), to a clean $15-\mathrm{mL}$ falcon tube and leaved to dryness. Samples were reconstituted in $500 \mathrm{uL}$ ACN containing, and analyzed by High Performance Liquid Chromatography (HPLC). 


\section{HPLC determination:}

Chromatographic separation was carried out according to Abdel-Ghany et al., (2017) using the Isco HPLC binary pump and Synergi Hydro RP C18 column $(250 \times 4.6 \mathrm{~mm} \mathrm{id}, 80 \AA, 4 \mu \mathrm{m})$ under isocratic conditions, where the mobile phase consisted of an acetonitrile- water mixture $(25+75, \mathrm{v} / \mathrm{v})$ at a flow rate of $1 \mathrm{~mL} / \mathrm{min}$. The samples $(10 \mu \mathrm{L})$ were injected into the liquid chromatograph system. Detection was performed at $250 \mathrm{~nm}$ for imidacloprid, thiamethoxam, acetamiprid, and 6-chloronicotinic acid (6-CNA). All chromatographic determinations were performed three times at ambient temperature, and the calibration curves constructed.

\section{Health risks to bees:}

To estimate the hazard to bees emanating from contaminated pollen loads, the pollen hazard quotient (PHQ) was calculated following Stoner and Eitzer (2013) and Traynor et al. (2016). This method was chosen as it provides a simple and comprehensive way to calculate the risk based on $\mathrm{LD}^{50}$-values easily available in the internet. The concentration of each pesticide found in a sample $(\mu \mathrm{g} / \mathrm{kg})$ was divided by the $\mathrm{LD}^{50}$ (honeybee oral; $\mu \mathrm{g} / \mathrm{bee}$ ) for the respective substance. $\mathrm{LD}^{50}$ values were obtained from the University of Hertfordshire pesticides properties database (PPDB, 2017), the US EPA ecotoxicology database (US EPA, 2017) or the Agritox database of the French government (2017). Based upon the average daily pollen consumption of a nurse bee $(9.5 \mathrm{mg} / \mathrm{bee} /$ day) (Crailsheim et al., 1992 \& Brodschneider and Crailsheim, 2010) a PHQ of $>50$ are considered "relevant". Assuming a daily pollen consumption of $9.5 \mathrm{mg}$ by a nurse bee (Traynor et al. 2016; Stoner and Eitzer, 2013 and Rortais et al., 2005) a PHQ of 50 would correspond to $0.05 \%$ of the $\mathrm{LD}^{50}$ consumed in one day (resulting in $0.5 \%$ of the $\mathrm{LD}^{50}$ in an average 10-day nursing period) (Stoner and Eitzer, 2013). HQ of 1000 corresponds to consuming $1 \%$ of the median lethal dose $\left(\mathrm{LD}^{50}\right)$ per day.

Total PHQ per sample (= day; tPHQday) was calculated as the sum of all PHQs of the pesticides in the respective sample.

\section{RESULTS AND DISCUSSION}

In this study, a validated, selective, and sensitive HPLC method for the analysis of neonicotinoid residues, imidacloprid, thiamethoxam, acetamiprid, and their primary metabolite6-chloronicotinic acid (6-CNA) was developed. The chromatographic conditions were studied and optimized. 
Under the previously mentioned chromatographic conditions, showed a peak at a tR of $1.83 \mathrm{~min}, 5.26 \mathrm{~min}, 7.48 \mathrm{~min}$ and $8.9 \mathrm{~min}$ for NIT, $6.9 \pm$ $0.3 \mathrm{~min}$ for 6-CAN, thiamethoxam, flonicamid, imidacloprid, and acetamiprid, respectively as presented in Figure (1).

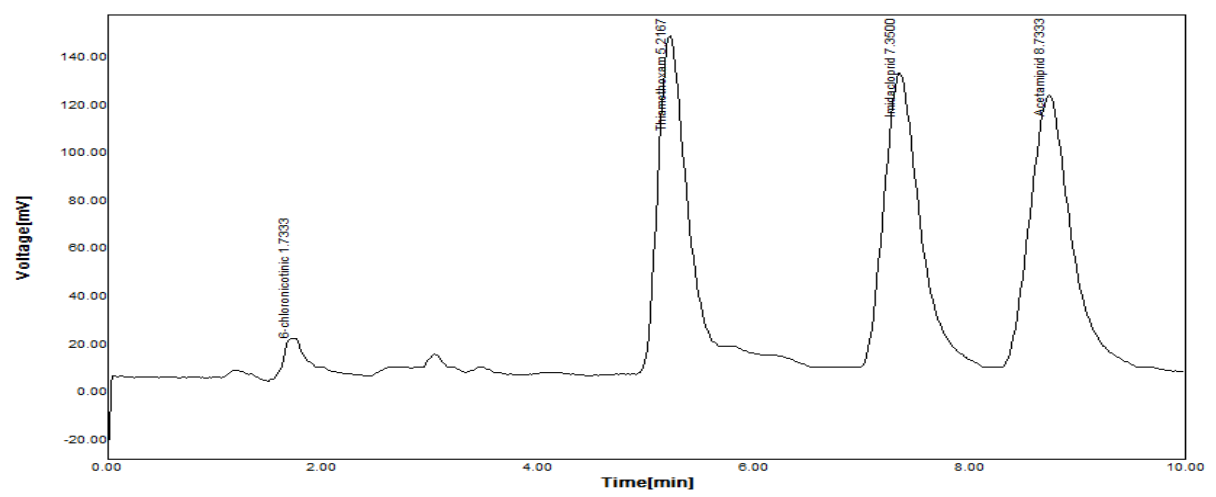

Figure (1): HPLC chromatogram of the neonicotinoids, imidacloprid, thiamethoxam, acetamiprid, flonicamid and their primary metabolite6-chloronicotinic acid (6-CNA) at $254 \mathrm{~nm}$.

Also, the total samples of pollen were analyzed by HPLC as mentioned in Figures (2: A, B, C, D and E).

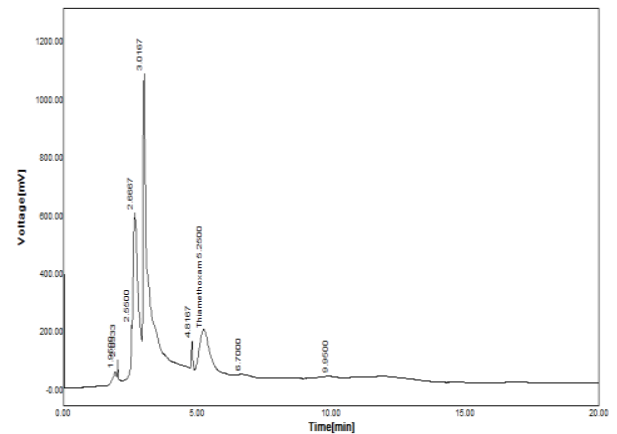

(A) Ezbet Issa

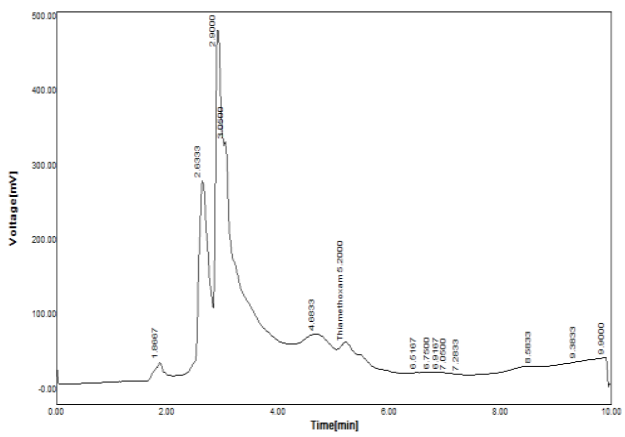

(B) El-Nakhas 


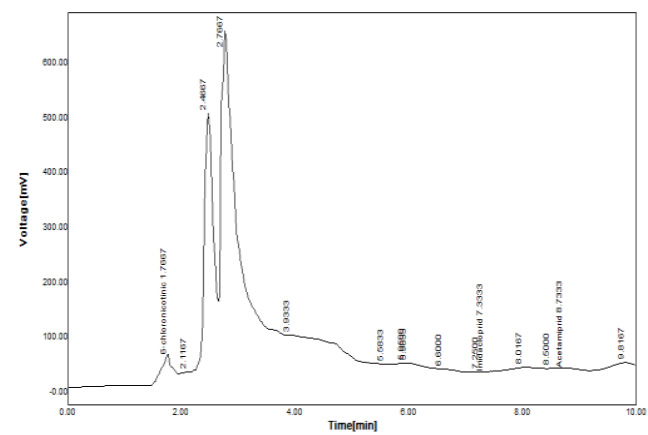

(C) Plant protection Institute

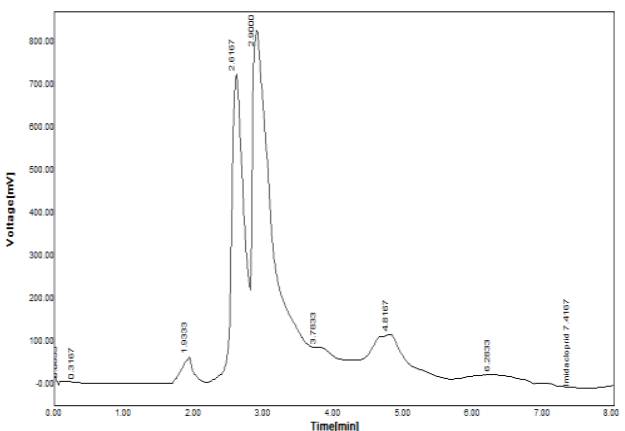

(D) $\underline{\text { Belbeis }}$

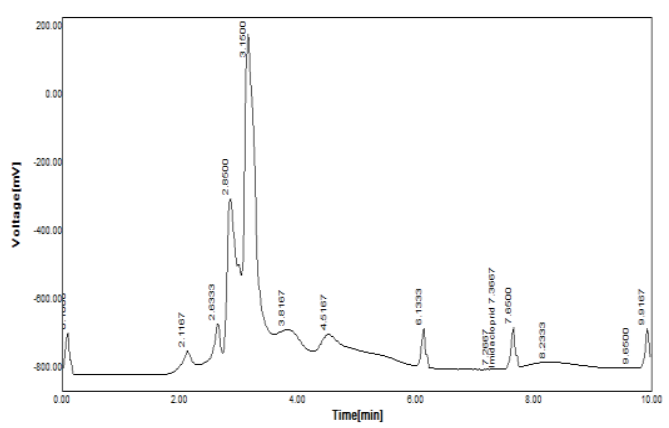

(E) Al-Mahmoudiyah

Figure (2). HPLC chromatogram of the pollen samples collected from several village (A, B, C, D and E) at Sharkia governorate, Egypt.

Data in Table (1) and Figure (3) show the concentration of neonicotinoidsin pollens collected from some village at Sharkia governorate, Egypt. 
Table (1): Concentration of some neonicotinoids in pollen grain in some villages in Sharkia Governorate, Egypt.

\begin{tabular}{|c|c|c|c|c|c|c|}
\hline Compounds & $\begin{array}{c}\text { Concentration } \\
(\mu \mathrm{g} / \mathrm{kg})\end{array}$ & \multicolumn{2}{|c|}{$\begin{array}{c}\text { LD }^{50} \\
\text { Contact } \\
\text { LD }^{50} \text { Oral LD } \\
\text { ug/bee ug/bee }\end{array}$} & \multicolumn{2}{|c|}{$\begin{array}{c}\text { Hazard } \\
\text { Quotients } \\
\text { (PHQ) }\end{array}$} & $\begin{array}{c}\text { MRL for } \\
\text { apicultural } \\
\text { products } \\
(\mu \mathrm{g} / \mathrm{kg}) \mathrm{h})\end{array}$ \\
\hline \multicolumn{7}{|l|}{ El-Nakhas } \\
\hline Thiamethoxam & 39 & 0.024 & 0.005 & 1625 & 7800 & 20 \\
\hline 6-chloronicotinic (6-CAN) & 145 & - & - & - & - & - \\
\hline \multicolumn{7}{|l|}{ Plant protection Institute } \\
\hline Imidacloprid & 021 & 0.081 & 0.0037 & 259 & 5675 & 50 \\
\hline Acetamiprid & 003 & 8.09 & 14.53 & 0.39 & 0.206 & 50 \\
\hline 6-chloronicotinic (6-CAN) & 299 & - & - & - & - & - \\
\hline \multicolumn{7}{|l|}{ Belbeis } \\
\hline Imidacloprid & 021 & 0.0439 & 0.0039 & 478 & 5384 & 50 \\
\hline \multicolumn{7}{|l|}{ Al-Mahmoudiyah } \\
\hline Imidacloprid & 0.022 & 0.0439 & 0.0039 & 478 & 5384 & 50 \\
\hline \multicolumn{7}{|l|}{ Ezbet Issa } \\
\hline Thiamethoxam & 056 & 0.024 & 0.005 & 2333 & 11200 & 20 \\
\hline
\end{tabular}

\begin{tabular}{|c|c|c|c|c|c|c|}
\hline \multirow{2}{*}{ 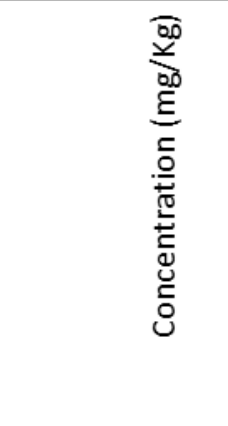 } & \multirow[t]{2}{*}{$\begin{array}{r}0.35 \\
0.33 \\
0.25 \\
0.2 \\
0.15 \\
0.1 \\
0.05 \\
0\end{array}$} & $\square$ & & $=$ & $n$ & a \\
\hline & & $\begin{array}{c}\text { El- } \\
\text { Nahas }\end{array}$ & $\begin{array}{c}\text { Plant } \\
\text { protecti } \\
\text { on } \\
\text { Institut } \\
\text { e }\end{array}$ & Belbeis & $\begin{array}{c}\text { Al- } \\
\text { Mahmo } \\
\text { udiyah }\end{array}$ & $\begin{array}{l}\text { Ezbet } \\
\text { Issa }\end{array}$ \\
\hline Thiamethoxam & & 0.039 & 0 & 0 & 0 & 0.056 \\
\hline = Imidacloprid & & 0 & 0.021 & 0.021 & 0.022 & 0 \\
\hline - Acetamiprid & & 0 & 0.003 & 0 & 0 & 0 \\
\hline 6-chloronicotini & 6-CAN) & 0.145 & 0.299 & 0 & 0 & 0 \\
\hline
\end{tabular}

Figure (3): Concentration of some neonicotinoids in pollen grain in some village in Sharkia Governorate, Egypt. 


\section{Residues determination}

Remarkable differences in residue levels between sites depending on the agricultural intensity were found. We found different pesticides in all observation sites. We found many samples under any detectable contamination and the few positive samples only with low concentrations of pesticides. Considering the maximum residue limits (MRL) of pesticides in apicultural products, Thiamethoxam pesticide exceeded their limits at ElNakhas and Ezbet Issa while imidacloprid less than their limits at Plant protection Institute, Belbeis and El-Mahmodia Table (1).

All pollen samples collected at the "fruit" site contained, on average 9.8 pesticides per sample. The lowest maximum concentrations were measured at "meadow", followed by "grain" and further exceeded by fruit with $294.6,1,496.4$ and 7,177.7 $\mu \mathrm{g} / \mathrm{kg}$, respectively (BoÈhme et al., 2018).

The highest concentrations found in our study, also being in $\mu \mathrm{g} / \mathrm{kg}$, were up to several times lower compared to the maximum concentrations reported by Stoner and Eitzer (2013), Traynor et al. (2016) and Mullin et al. (2010), where pesticide concentrations exceeded 10,000, 20,000 and even 90,000 $\mu \mathrm{g} / \mathrm{kg}$. This is in accordance with an evaluation by Johnson et al. (2010) who affirms that it is not unusual to find $\mathrm{mg} / \mathrm{kg}$ residue levels in hive matrices or collected goods of honeybees when foraging in conventionally farmed land or as pollinators in monocultures with no alternative flowers. Data on pesticide residues in pollen, honey and wax from bee hives were taken from several sources, including recent pesticide surveys in the USA (Mullin et al., 2010, Rennich et al., 2012) France (Chauzat et al., 2011) and Spain (Bernal et al., 2010). The highest residue concentrations were found in wax and pollen (average 126 and $66 \mu \mathrm{g} / \mathrm{kg}$ respectively), whereas the highest frequency of detection corresponds to wax (over $50 \%$ for chlorfenvinphos, tau-fluvalinate, bromopropylate, coumaphos and chlorothalonil) and honey (over 50\% for thiacloprid, thiamethoxam and acetamiprid (Pohorecka et al., 2012).

\section{Pollen hazard quotient}

Pollen hazard quotients (PHQ) are calculated based on LD50 values and therefore represent the toxicity of substances. Hence, very toxic substances yield in high PHQ values. The PHQ values ranged between 0.206 and 7800 within all samples, sites and pesticides. Thiamethoxam at El-Nakhas and Ezbet Issa and imidacloprid at Plant protection Institute, Belbeis and El-Mahmodia record a higher PHQ more than 1000 corresponds to consuming more than $1 \%$ of the median lethal dose (LD50) per day and therefore represent the toxicity of substances to honey. Hence, very toxic 
substances yield in high PHQ values. Thiamethoxam exceeded at Ezbet Issa and El-Nakhas 25.4 and 15.6 times even a threshold of 500 (max. 600) Table (1). While imidacloprid exceeded at Plant protection Institute, Belbeis and El-Mahmodia 11.35, 10.76 and 10.76 times even a threshold of 500 (max. 600) Table (1). A PHQ of 50 would correspond to $0.05 \%$ of the $\mathrm{LD}_{50}$ consumed in one day (resulting in $0.5 \%$ of the $\mathrm{LD}_{50}$ in an average 10-day nursing period) (Stoner and Eitzer, 2013) Acetamiprid at Plant protection Institute the lowest PHQ were calculated and did not exceed relevant thresholds (max. PHQ 25.56). The PHQ values ranged between 0.002 and 600 within all observation years, sites and pesticides. At ${ }^{a}$ meadow ${ }^{\circ}$ site the lowest PHQ were calculated and did not exceed relevant thresholds (max. PHQ 25.56) (BoÈhme et al., 2018).The "relevant threshold of 50" (Stoner and Eitzer, 2013) has been exceeded six times by the pesticides methiocarb and dimethoate at "grain" site (max. 164.41) and twelve times at "fruit" site by the pesticides dimethomorph, fenhexamid, fluazifop and indoxacarb. Clothianidin and imidacloprid exceeded at "fruit" site four times even a threshold of 500 (max. 600; during the three years of observation (BoÈhme et al., 2018). Sanchez-Bayo and Goka (2014) show residues of pyrethroid and neonicotinoid insecticides pose the highest risk by contact exposure of bees with contaminated pollen. However, the synergism of ergosterol inhibiting fungicides with those two classes of insecticides results in much higher risks in spite of the low prevalence of their combined residues. Risks by ingestion of contaminated pollen and honey are of some concern for systemic insecticides, particularly imidacloprid and thiamethoxam, chlorpyrifos and the mixtures of cyhalothrin and ergosterol inhibiting fungicides.

Experiments with bumble bees have demonstrated that the lethal effects of new insecticidal compounds, including insect growth regulators and neonicotinoids, cannot be assessed based on acute toxicity data alone (Mommaerts et al., 2010).What is clear from the dietary assessment shown here is that systemic insecticides rank at the top of the list of risky chemicals: thiamethoxam, clothianidin, imidacloprid, dinetofuran, and to a lesser extent methiocarb, dimethoate and carbaryl (Sanchez-Bayo and Goka 2014). Moreover, the risk of neonicotinoids by dietary exposure above appears to be underestimated because it is known that these insecticides have chronic toxicities that exceed the known acute toxicities (Laurino et al., 2013). 
Conclusively,

From these results it could be concluded that risks by ingestion of contaminated pollen and honey are of some concern for systemic insecticides, particularly imidacloprid and thiamethoxam, chlorpyrifos and the mixtures of cyhalothrin and ergosterol inhibiting fungicides. However, residues of neonicotinoid insecticides pose the highest risk by contact exposure of bees with contaminated pollen.

\section{REFERENCES}

Abdel-Ghany, Maha F.; Hussein, Lobna A.; El Azab, Noha F. (2017). Multiresidue Analysis of Five Neonicotinoid Insecticides and Their Primary Metabolite in Cucumbers and Soil Using High-Performance Liquid Chromatography with Diode-Array Detection. Journal of AOAC International, 100 (1): 176-188.

Bernal, J.; Garrido-Bailon, E.; Nozal, M.J.D.; Gonzalez-Porto, A.V. and Martin-Hernandez, R. (2010). Overview of pesticide residues in stored pollen and their potential effect on bee colony (Apis mellifera) losses in Spain. Journal of Economic Entomology, 103: 1964-1971.

BoÈhme, F.; Bischoff, G.; Zebitz, C.P.W.; Rosenkranz, P. and Wallner, K. (2018). Pesticide residue survey of pollen loads collected by honeybees (Apis mellifera) in daily intervals at three agricultural sites in South Germany. PLOS ONE.

Bonmatin, J.M.; Giorio, C.; Girolami, V.; Goulson, D.; Kreutzweiser, D.P.; Krupke, C.; Liess, M.; Long, E.; Marzaro, M.; Mitchell, E.A.D.; Noome, D.A.; Simon-Delso, N. and Tapparo, A. (2015). Environmental fate and exposure; neonicotinoids and fipronil. Environ. Sci. Pollut. Res., 22: 35-67.

Botías, C.; David, A.; Hill, E. and Goulson, D. (2016). Contamination of wild plants near neonicotinoid seed-treated crops, and implications for non-target insects. Environ. Sci. Technol., 566-567:269-278.

Botías. C.; David, A.; Horwood, J.; Abdul-Sada, A.; Nicholls, E.; Hill, E. and Goulson, D. (2015). Neonicotinoid residues in wildflowers, a potential route of chronic exposure for bees. Environ. Sci. Technol., 49: 12731-12740.

Brodschneider, R. and Crailsheim, K. (2010). Nutrition and health in honey bees. Apidologie., 41: 278-294. 
Chauzat, M.P.; Martel, A.C.; Cougoule, N., Porta, P. and Lachaize, J. (2011). An assessment of honeybee colony matrices, Apis mellifera (Hymenoptera: Apidae) to monitor pesticide presence in continental France. Environmental Toxicology and Chemistry, 30: 103-111.

Codling, G.; Al Naggar-Giesy J.P. and Robertson, A.J. (2016). Concentrations of neonicotinoid insecticides in honey, pollen and honey bees (Apis mellifera L.) in central Canada, Chemosphere, 144: 2321-2328.

Crailsheim, K.; Schneider, L.H.W.; Hrassnigg, N.; Bühlmann, G.; Brosch, U.; Gmeinbauer, R. and Schöffmann, B. (1992). Pollen consumption and utilization in worker honeybees (Apis melliferacarnica): Dependence on individual age and function. $J$. Insect Physiol., 38: 409-419.

Cutler, G.C.; Scott-Dupree, C.D. and Drexler, D.M. (2014). Honey bees, neonicatinoids and reports of incidents of mortality of bees: the Canadian situation. Pest Manag. Sci., 70: 779-783.

Fairbrother, A.; Purdy, J.; Anderson, T. and Fell, R. (2014). Risks of neonicotinoid insecticides to honeybees. Environ. Toxicol. Chem., 33, 719-731.

Johnson, R.M.; Ellis, M.D.; Mullin, C.A. and Frazier, M. (2010). Pesticides and honey bee toxicity. USA. Apidologie., 41: 312-331.

Klein, O. (1987). Biokinetic part of the 'General metabolism study' in the rat. Unpublished report from Bayer AG, report No. PF2889, dated 9 November 1987, GLP. Submitted to WHO by Bayer AG, Mannheim, Germany.

Laurino, D.; Manino, A.; Patetta, A. and Porporato, M. (2013). Toxicity of neonicotinoid insecticides on different honey bee genotypes. Bulletin of Insectology. 66: 119-126.

Main, A.R.; Headley, J.V.; Peru, K.M.; Michel, N.L.; Cessna, A.J. and Morrissey, C.A. (2014). Widespread use and frequent detection of neonicotinoid insecticides in wetlands of Canada's Prairie Pothole Region. PLoS ONE, 9: e92821.

Mogren, C.L. and Lundgren, J.G. (2016). Neonicotinoid-contaminated pollinator strips adjacent to cropland reduce honey bee nutritional status. Sci. Rep., 6: 29608.

Mommaerts, V.; Reynders, S.; Boulet, J.; Besard, L. and Sterk, G. (2010). Risk assessment for side-effects of neonicotinoids against bumblebees with and without impairing foraging behavior. Ecotoxicology, 19: 207-215. 
Mullin, C.A.; Frazier, M.; Frazier, J.L.; Ashcraft, S.; Simonds, R. and van-Engelsdorp, D. (2010). High levels of miticides and agrochemicals in North American apiaries: implications for honey bee health. PLoS One, 5(3): e9754. https://doi.org/10.1371/ journal.pone.0009754 PMID: 20333298.

Pecenka, J.R. and Lundgren, J.G. (2015). Non-target effects of clothianidin on monarch butterflies. Sci. Nat., 102:19.

Pohorecka, K.; Skubida, P.; Miszczak, A.; Semkiw, P. and Sikorski, P. (2012). Residues of neonicotinoid insecticides in bee collected plant materials from oilseed rape crops and their effect on bee colonies. Journal of Apicultural Science, 56: 115-134.

PPDB-Pesticide Properties DataBase, Univesity of Hertfordshire, (2017). Available from: http://sitem. herts.ac.uk/ aeru/ppdb/ en/ atoz. htm \#A. Accessed on 2017-02-20.

Rennich, K.; Pettis, J.; van-Engelsdorp, D.; Bozarth, R. and Eversole, H. (2012). 2011-2012 National Honey Bee Pests and Diseases Survey Report. USDA.17 p.

Rortais, A.; Arnold, G.; Halm, M.P. and Touffet-Briens, F. (2005). Modes of honey bees exposure to systemic insecticides: estimated amounts of contaminated pollen and nectar consumed by different categories of bees. Apidologie., 36: 71-83.

Rundlöf, M.; Andersson, G.K.S. and Bommarco, R. (2015). Seed coating with a neonicotinoid insecticide negatively affects wild bees. Nature, 521: 77-80.

Sanchez-Bayo, F. and Goka, K. (2014). Pesticide Residues and Bees - A Risk Assessment. PLOS ONE, 9 (4): e94482.

Simon-Delso, N.; Amaral-Rogers, V.; Belzunces, L.P.; Bonmatin, J.M.; Chagnon, M.; Downs, C.; Furlan, L.; Gibbons, D.W.; Giorio, C.; Girolami, V.; Goulson, D.; Kreutzweiser, D.P.; Krupke, C.H.; Liess, M.; Long, E.; McField, M.; Mineau, P.; Mitchell, E.A.D.; Morrissey, C.A.; Noome, D.A; Pisa, L.; Settele, J.; Stark, J.D.; Tapparo, A.; Van Dyck, H.; Van Praagh, J.; Van derSluijs, J.P.; Whitehorn, P.R. and Wiemers, M. (2015). Systemic insecticides (neonicotinoids and fipronil): trends, uses, mode of action and metabolites. Environ. Sci. Pollut. Res. 22, 5e34.

Stewart, S.D.; Lorenz, G.M. and Catchot, A.L. (2014). Potential exposure of pollinators to neonicotinoid insecticides from the use of insecticide seed treatments in the mid-southern United States. Environ Sci. Technol., 48: 9762-9769. 
Stoner K.A. and Brian D.E. (2013). Using a Hazard Quotient to Evaluate Pesticide Residues Detected in Pollen Trapped from Honey Bees (Apis mellifera) in Connecticut. PLOS ONE, 8 (10): e77550.

Stoner K.A. and Eitzer B.D. (2013). Using a hazard quotient to evaluate pesticide residues detected in pollen trapped from honey bees (Apis mellifera) in Connecticut. PLoS One. 8: 1 \pm 10 . https://doi.org/ 10.1371/ journal.pone.0077550 PMID: 24143241.

Syngenta, Global (2012). 2011 Full Year Results. http://www. syngenta.com/global/corporate/en/news-center/news-releases/ pages/ 120208 .aspx.

Syngenta, Global (2013). 2012 Full Year Results. http://www. syngenta. com/global/corporate/SiteCollectionDocuments/pdf/media-releases/ en/ 20130206-analystpresentation- fyr2012.pdf.

Traynor, K.S.; Pettis, J.S.; Tarpy, D.R.; Mullin, C.A.; Frazier, J.L. and Frazier, M. (2016). In-hive Pesticide Exposome: Assessing risks to migratory honey bees from in-hive pesticide contamination in the Eastern United States. Nature Sci. Reports. 6: 1-16.

US EPA. (2017). United States Environmental Protection Agency ecotoxicology database 2017. Available from: https://cfpub. epa. gov/ ecotox/. Accessed on , 2017-04-10.

$$
\begin{aligned}
& \text { تقيم المخاطر المحتملة لتلوث حبوب اللقاح بمتبقيات المبيدات وتأثثراتها }
\end{aligned}
$$

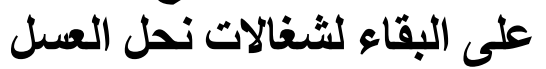

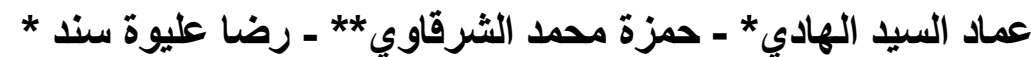

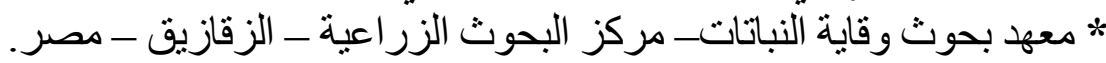

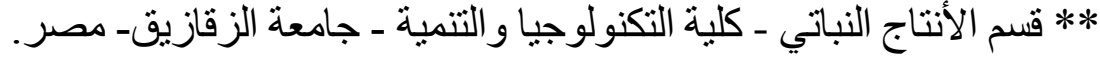

$$
\begin{aligned}
& \text { أنشارت بعض الدراسات إلى أن الاستخدام الواسع النطاق للمبيدات الحثرية قد }
\end{aligned}
$$

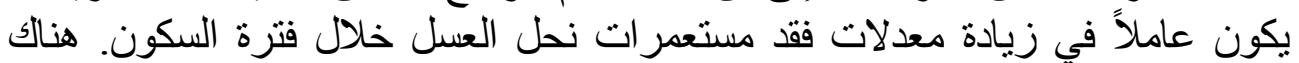

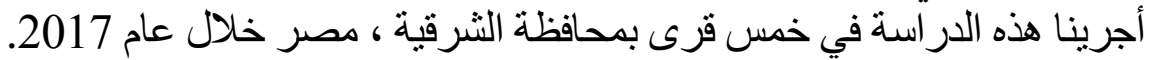


كثنف النتائج التي تم الحصول عليها عن وجود فروق ملحوظة في مستويات

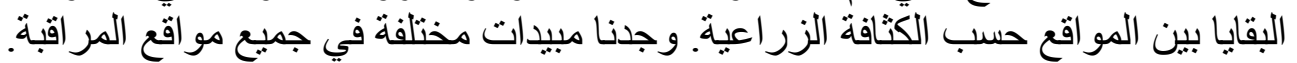

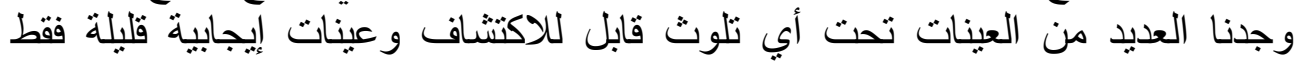

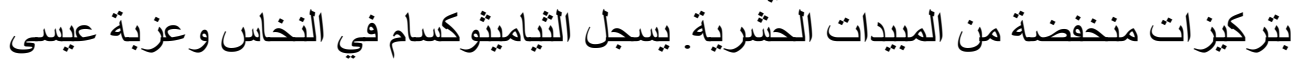

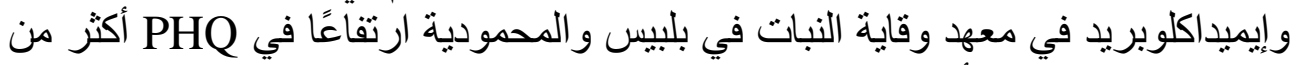

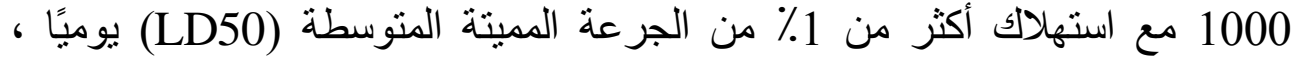
وبالتالي يمثلان سمية المو اد إلى العسل. التوصية: من هذه النتائج ، يمكن استنتاج أن التخل المخاطر الناجمة عن ثتاول حبوب اللقاح

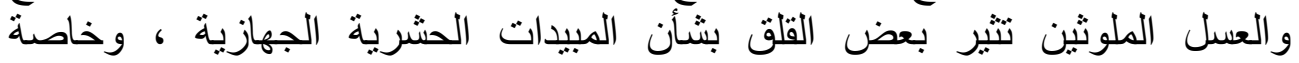

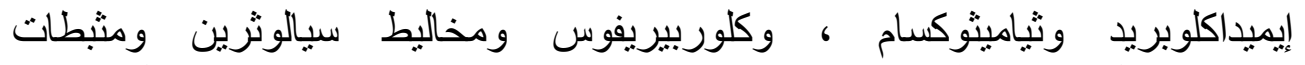

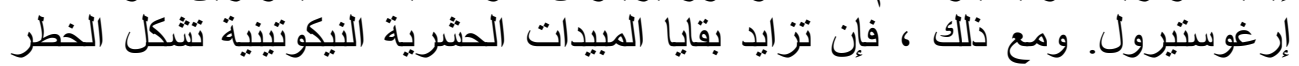

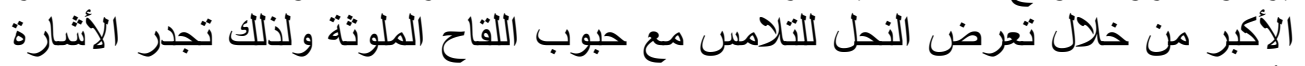
بأهمية الحد من إستخدام هذة المبيدات على نطاق لحن واسع. 